\title{
International capital flows, stock markets, and uneven development: the case of Sub-Saharan Africa and the Sustainable Stock Exchanges Initiative (SSEI)
}

https://doi.org/10.1515/zfw-2017-0038

Received: November 21, 2017; accepted: March 2, 2018

Abstract: While for a long time only regarded as subordinate factors, it is meanwhile accepted that financial systems and capital flows play a key role for economic development and growth. Against this background many countries of the Global South founded new, or liberalised existing, stock exchanges, albeit with different results. Whereas in various Asian countries these markets have attracted sizable amounts of investment capital for domestic companies, this is not the case for most stock exchanges in Africa and especially Sub-Saharan Africa. Although there is an increasing number of Sub-Saharan African stock exchanges, the majority is institutionally weak, small, illiquid and thus unattractive to most international investors, resulting in low portfolio investment inflows to Sub-Saharan Africa. Nonetheless, Africa is becoming increasingly portrayed as continent of opportunities with immense growth prospects which led to a new and growing appetite for investment in Africa in general and Sub-Saharan Africa in particular. In this situation the new UN-supported Sustainable Stock Exchanges Initiative (SSEI) comes into play which aims at transforming stock markets into instruments for supporting sustainable development and green growth. Based on conceptual considerations surrounding the development-through-stock-exchanges argument, this exploratory research addresses the actors involved in this initiative and takes their rationales under closer scrutiny. We argue that the initiative not only serves as a tool for sustainable development, but also as a promoter and facilitator of new international investment opportunities, specifically for international and institutional investors in their drive to enlarge and diversify their portfolios - result-

\footnotetext{
*Corresponding author: Britta Klagge, Department of Geography, University of Bonn, Meckenheimer Allee 166, D-53115 Bonn, Germany, e-mail: klagge@uni-bonn.de Hans-Martin Zademach, Fachbereich Geographie, Katholische Universität Eichstätt-Ingolstadt, Ostenstraße 18, 85072 Eichstätt, Germany
}

ing in various challenges for Sub-Saharan stock exchanges and their local stakeholders.

Keywords: developing countries; emerging economies; international finance; market making; stock market; Sub-Saharan Africa; sustainable development.

\section{Introduction}

Financial markets as well as international capital flows have been recognized as important drivers of economic as well as social development (Schumpeter 1912; Myrdal 1957). Despite the theoretically given unlimited fluidity of money, national and regional economies are differently integrated into global capital circuits and thus into the world economy. As is by now widely acknowledged, financial sectors - and more generally financial systems play an important role for capital flows and thus economic development and growth at various scales (McKinnon 1973; Martin 1999; Levine 2005). It is against this backdrop that IMF and World Bank, often starting as part of structural adjustment programs in the 1980s and 1990s, have increasingly focused on financial-sector reform and liberalisation in countries of the Global South. The development of stock markets which are open to international investment has become an important - albeit not uncontroversial - element in this approach and is associated with the hope to "attract ... private capital investment and integration into the global financial marketplace" (Kenny/Moss 1998, 830, with special reference to Africa). As a result, many countries of the Global South founded new, or liberalized existing, stock exchanges. Whereas in some cases, mainly in some Asian countries, these have attracted sizable amount of investment capital for domestic companies, this is not the case for most stock exchanges in Africa, which are "insignificant compared to other emerging markets” (Ncube/Mingiri 2015, 368).

Although it has abundant natural resources, Africa, and Sub-Saharan Africa in particular, remains the world's 
poorest continent whose integration into the world economy remains extremely low with very small shares of global trade and capital flows, both foreign direct and portfolio investment (WB 2017a). Nonetheless - or maybe because of this - Africa becomes increasingly portrayed as sleeping giant ("schlummernder Riese") and continent of opportunities with immense growth prospects ("Chancenkontinent Afrika”, SWR 2017; also see BDI 2015, IFC 2011). This forecast, or rather vision, has led to a new and growing "appetite for investment in Sub-Saharan Africa" by global emerging market investors (IFC 2011, 8, 19). The greater attention to Africa as an investment destination, especially as a "good investment opportunity for portfolio diversification for international investors" (Ncube/Mingiri $2015,370)$, is reflected in a still small, but increasing number of international investment funds focusing on Africa. However, these funds mainly invest in a limited number of countries and focus on firms listed on one of the few larger stock markets in Sub-Saharan Africa, specifically in South Africa, Nigeria and Kenya (IFC 2011). ${ }^{1}$ Generally, stock exchanges provide the most important channel through which foreign portfolio investment is processed, and most international and institutional investors focus on large exchanges, which "tend to be less volatile, more liquid, and less concentrated in a few stocks" (Demirgüc-Kunt/Levine 1996, 317). The majority of stock exchanges in Sub-Saharan Africa, however, are very small and illiquid, thus constituting a major bottleneck for foreign investment in the region (Allen et al. 2011; IFC 2011; Ncube/Mingiri 2015). This and, more generally, the weak integration of Sub-Saharan Africa into the world economy, are regularly seen as one of the reasons for enduring poverty and lack of growth in many parts of Sub-Saharan Africa.

It is in this situation that various UN-related organisations (UNCTAD, UNGC, UNEP-FI, PRI) ${ }^{2}$ have started a top-down initiative for stock exchanges worldwide which aims at transforming them into instruments for supporting sustainable development and so-called green growth. The Sustainable Stock Exchanges Initiative (SSEI) was established in 2009 and has concurrently (end of 2017) 66 partner exchanges representing almost 70 countries, out of which more than a quarter are in Sub-Saharan Africa. It is certainly too early to produce an encompassing eval-

1 Similarly, although there are more than 50 general and specialised sustainability indices, only seven of them are associated with stock exchanges in developing countries; in Sub-Saharan Africa, South Africa is the only country included (Vives/Wadhwa 2012).

2 United Nations Conference on Trade and Development (UNCTAD), UN Global Compact (UNGC), United Nations Environment Programme Finance Initiative (UNEP-FI), and Principles for Responsible Investment Initiative (PRI, also supported by the UN). uation of the SSEI's role for the development of Sub-Saharan Africa stock exchanges and for the better integration of Sub-Saharan Africa into the world economy. However, it appears to be a good point in time to take the actors involved and their rationales under closer scrutiny, which is the aim of this exploratory paper.

Based on the preliminary evidence available, we argue that one key rationale of the SSEI, especially in the Sub-Saharan Africa context, is the function of a "market maker". By this, we do not refer to the rather narrow meaning in the literature in finance, which means a stock exchange agent who, by buying and selling, guarantees market liquidity for his or her securities. Rather, we conceptualize the terms market maker and market making in a broader sense. We are inspired by the social-science literature on marketization that discusses "how real markets, in all their hybrid and heterogeneous appearances, are produced, stabilized, and dissolved" (Berndt/Boeckler 2010, 200). Ouma (2015, 26, 38) especially highlights the role of a variety of actors, especially governments, service providers and international (development) organisations, for "extending the frontier regions of marketization to the Global South". This is of specific interest to our study, and we argue, more concretely, that the SSEI, while officially focusing on sustainable investment, serves as a promoter and facilitator of new international investment opportunities, thus especially benefitting international and institutional investors in their drive to enlarge and diversify their portfolios. This is especially relevant with regard to smaller Sub-Saharan African stock markets, which have "proved relative immune to global tensions ... due to their lack of correlation with developed markets", thus offering "positive benefits in terms of risk diversification" (Ncube/ Mingiri 2015, 370).

In our paper we address the following research questions: How can stock exchanges be(come) relevant for economic development in the Global South? How are Sub-Saharan economies and stock exchanges integrated into international capital flows? In which ways does the SSEI support the better integration of Sub-Saharan Africa into the world economy? Who are the relevant actors and potential beneficiaries? What are the resulting challenges? We address these questions in an exploratory manner, based on the analysis of the most recent data on international capital flows by the World Bank (WB 2017a) as well as on stock exchanges, specifically in Sub-Saharan Africa by the World Bank (WB 2017b), the World Federation of Exchanges (WFE 2017a, 2017b), the International Finance Corporation (2011), the African Securities Exchanges Association (ASEA 2017) and the SSEI (various sources). In addition, we triangulated our findings with a thorough 
literature review and the analysis of international policy documents on stock exchanges (WFE 2017a), sustainable investment in Sub-Saharan Africa (IFC 2011) and on the structure, aims and workings of the SSEI.

The remainder of the paper is structured as follows: The next section provides a survey of the theoretical discussion on the relationship between stock markets and economic growth with a special emphasis on developing and emerging economies ${ }^{3}$ (2.1) and conceptually explores national stock exchanges as localized institutions and their role for foreign investment (2.2). Subsequently, some background information on international capital flows, portfolio investment and stock markets worldwide with special attention to Sub-Saharan Africa are given (section 3), followed by a more detailed account of Sub-Saharan African stock exchanges (section 4). Section 5 introduces the SSEI, its founding context and (official) rationale, and the development of its partner exchanges. Section 6 then looks at Sub-Saharan stock exchanges' participation in SSEI and at the potential beneficiaries. The final section discusses the findings in light of the research questions and the theoretical considerations and concludes with the resulting challenges for Sub-Saharan stock exchanges and their local stakeholders.

\section{Financial development, stock exchanges and economic growth: conceptual considerations}

While long time only regarded as a subordinate factor (e.g. Lucas 1988), it is meanwhile widely accepted that the financial system is key for economic and social development (e.g. Dymski 2005; Stiglitz 2010; Beck 2012). However, there is still a lively debate in which concrete form (e.g. bank- vs. market-based, centralised vs. decentralised, demand-following vs. supply-leading systems) the financial sector is better suited to advance emerging and developing economies (e.g. Levine 2002; Rodríguez-Fuentes 2006; Arcand et al. 2012; Asongu/De Moor 2017). In the following we will first sketch the arguments around the potential merits and problems of stock exchanges and thereby address the question why international organisations are interested in, and indeed do, support stock exchange devel-

3 A generally accepted classification for determining which countries are considered emerging and developing economies does not exist. Usage of the term here follows the classification of the World Bank and the IMF as specified in detail in the World Economic Outlook database. opment. We will then take a closer look at different types of stock exchanges and discuss why, even in a globalized world with well-functioning electronic trading systems, national stock exchanges still have a role to play.

\subsection{Stock exchanges and economic growth: a double-edged sword}

The question whether stock exchanges promote economic development or not has a long history, with first important contributions dating back to the seminal works of John Maynard Keynes (1936) and William Baumol (1965). Especially since the 1980s and 1990s, i.e. the era celebrating the virtues of markets, there has been a fascination with stock markets and their potential for kick-starting lagging economies and, more generally, accelerating growth. Since then, stock markets have surged worldwide, with emerging markets such as Brazil, Chile and South Africa accounting for a large share of this boom (e.g. Wójcik/ Burger 2010). At the same time, the body of theoretical work on the relationship between stock market development and economic growth has increased considerably. Notwithstanding this long history, there is no consensus on the pros and cons of stock markets for economic growth, especially when it comes to the developing world in general and the African context in particular.

In mainstream economic thinking, the line of argument is quite straightforward: Stock markets encourage economic growth by providing a boost to domestic savings and increasing the quantity and the quality of investment. In particular, stock markets are seen to promote growth by providing an avenue for growing companies to raise capital at lower cost. This can reduce the risk of a credit crunch, as companies are less dependent on bank financing. In addition, stock markets are regarded as valuable tools for mobilizing savings and increasing the savings rate of individuals by allowing for allocating savings to investment projects with higher returns. In consequence, more savings may be channelled to the corporate sector. In addition, stock markets as (potentially) liquid markets, where capital can be allocated and withdrawn easily, are expected to ensure efficiency of capital allocation and thus promote financial discipline ('takeover mechanism'). The presumption is that, if management does not maximize firm value, another economic agent may take control of the firm, replace management, and reap the gains from a more efficient firm. In other words, a free market of corporate control is regarded to provide the best guarantee of efficiency in the use of capital and other assets. 
This efficiency-of-stock-markets narrative, as well as the closely related development-through-stock-exchanges argument, is, however, not uncontested. Critics argue that the pricing and takeover mechanism even in well-developed stock markets may lead to short-termism and lower rates of long-term investment, particularly in firm-specific human capital. Most notably, the stock market is seen to generate perverse incentives, rewarding managers for their success in financial engineering rather than creating new wealth through organic growth. In addition, the disciplinary function of stock markets is questioned on basis of the observation that competitive selection in the market for corporate control takes place more on the basis of size rather than performance, leading to large inefficient firms having higher chances of survival than smaller, relatively more efficient firms. Furthermore, critics argue that stock market liquidity can negatively influence corporate governance. This is particular the case, when very liquid stock markets allow investors to sell their shares very easily, thus weakening the commitment and incentive of investors to exert corporate control (for a fuller discussion of the pros and cons of stock markets for economic development see Demigüc-Kunt/Levine 1996; Kenny/Moss 1998; Singh 1999; Wójcik 2007).

The empirical evidence addressing the relationship between stock market development and economic growth is mixed, but on balance in favour of a positive nexus (Kenny/Moss 1998; Yartey 2008; Dike 2016). A study on the relationship between stock market development and economic growth in seven Sub-Saharan countries, for example, suggests different directions of causality and argues in favour of political encouragement of stock market development in Africa (Enisan/Olufisayo 2009). Levine and Zervos (1998) have shown that stock market development plays an important role for future economic growth, and that this association is particularly strong in developing countries, thus providing a rationale for stock market promotion by international organisations. However, especially in developing countries with weaker regulatory institutions and greater macroeconomic volatility such as in Sub-Saharan Africa, stock markets carry the risk of magnifying the adverse effects discussed above (Yartey 2008; Afego 2015; see more generally Arcand et al. 2012). Given the differentiated system of stock exchanges worldwide, we will focus in the following on what are conceptual reasons to support national stock exchanges in contrast to the centralisation of activities in large international exchanges, e.g. in Johannesburg or even London.

\subsection{The geography of stock exchanges: national exchanges as entry points for international investors}

Despite the increasing digitisation of stock exchange activities, there is a variety of different types and sizes of stock exchanges, from large international - or rather global players such as the New York and London Stock Exchange over more international-regional (e.g. Frankfurter Börse, Euronext in Europe) or international-specialised (e.g. Luxembourg Stock Exchange) to smaller national or even regional exchanges. Why stock exchanges (still) exist as localised organisations, has been a topic in the geography of finance for some time (Grote 2009; Schamp 2009; Dörry 2015; Klagge et al. 2017). The arguments for centralisation revolve around economies of scale, whereas localisation is supported by the need for proximity to various market actors. In his study of the Warsaw stock exchange, Wójcik (2007) gives a detailed account of who these market actors are and how proximity is beneficial or even a requirement for certain stock exchange activities. He also points out how a national stock exchange can be an important entry point for international investors to get access to smaller domestic companies. His findings provide important insights for the exploration of Sub-Saharan African stock exchanges.

A stock exchange brings together companies in need of capital and capital providers. By regulating the emission of, and trade in, securities, and specifically the access for both companies and investors, it helps to mitigate risk and provides an organised and rather transparent framework for capital investment. Figure 1 gives a general overview of how stock exchanges are at the centre of a network of different stakeholders - including not only the supply and the demand side, but also various service providers - and their most important functions. In the following we will use this framework as a starting point to discuss national stock exchanges and how they provide an entry point for international investors.

Stock exchanges are important partners for their listed companies and are always in search of new companies to be listed. They gather and process exclusive knowledge on businesses in their region or country and can, through their specific expertise, act as 'scouts' and 'gate keepers' at the same time. By selecting and listing certain companies (and not others) they signal to investors that these companies are "investor-ready". In stock exchanges' knowledge management geographical proximity and "leveraging local knowledge" (IFC 2011, 67-68) play an important role, especially with respect to smaller companies, but also when stock exchanges operate in opaque business envi- 
Policy makers

decide on tax, legal and regulatory policies

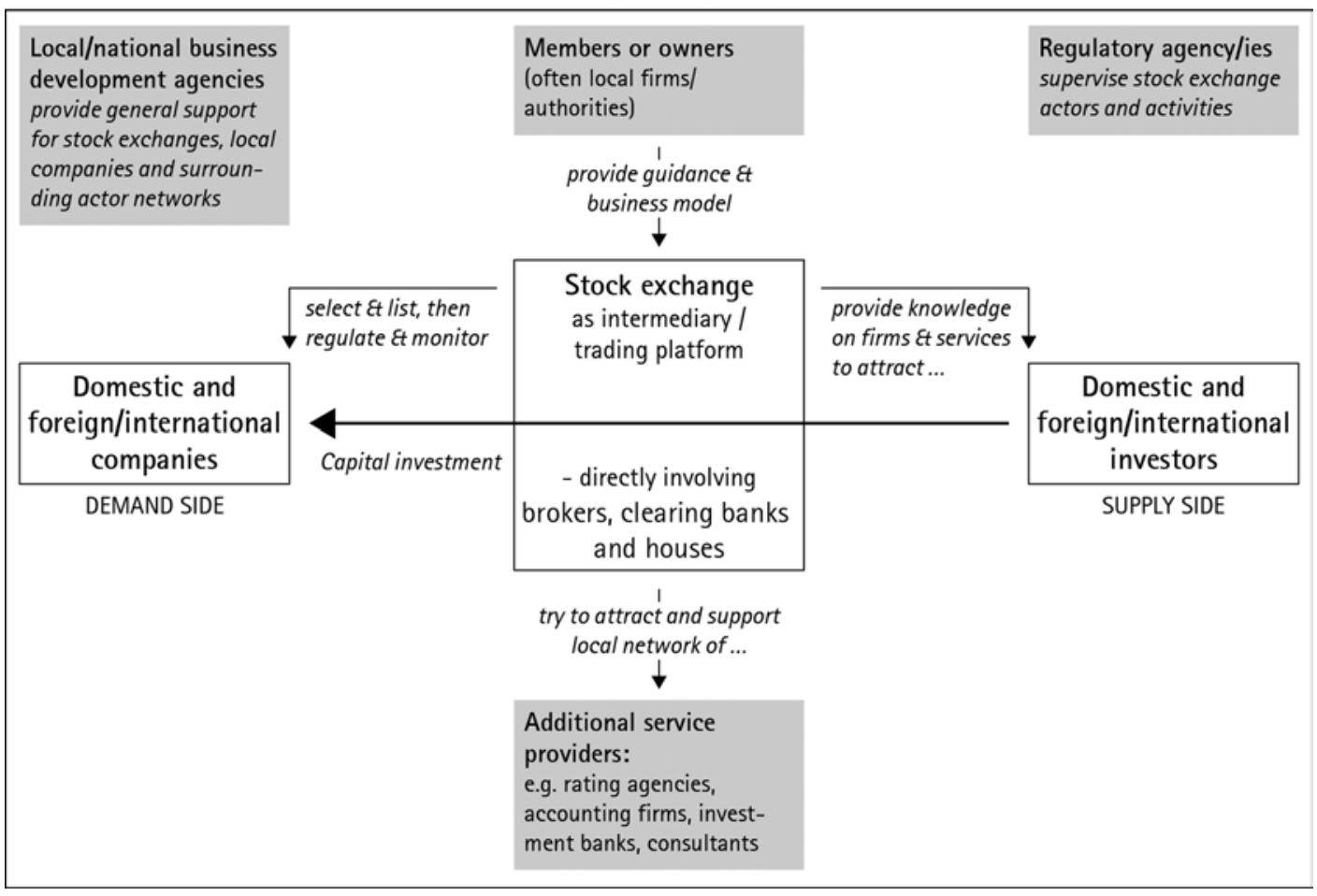

Figure 1: Stock exchange actors and important network relationships. Authors' illustration.

ronments such as Sub-Saharan Africa (or Poland after the fall of the Iron Curtain, cf. Wójcik 2007). ${ }^{4}$ In such environments, national stock exchanges often act, in the sense explained in the introduction, as market makers which not only select, but often also have to convince companies to become listed. This and the preceding scouting of suitable companies is an important task of national stock exchanges which could not (easily) be done from greater geographical distance (Dörry 2017).

These activities and their specific expertise make localised stock exchanges important partners of investors both domestically and also internationally. Generally, stock exchanges supply investors with knowledge on their listed companies and provide their services as a trading platform. Furthermore, investor relations also include the active development and enlargement of a stock exchange's investor base via marketing and promotion - which is a necessary correlate of the market making described above. Whereas international investors are usually predominantly interested in larger companies and so-called blue chips, the local and national investor community tends to

4 For a detailed analysis of the role of proximity in knowledge management in finance networks and investor-firm relationships see, for example, Klagge/Peter (2011, 2012) and Peter (2018). be more prone to investment in a greater variety of firms. In consequence, domestic investors, and more generally domestic savings and investment, are important as they provide the resources for smaller growing into large(r) firms and thus become attractive to international investors as well. It is against this background that most stock exchanges pursue investor relations strategies at various levels. This is especially relevant in markets where there is not (yet) an established local investor base and a lack of, or only weak, domestic participation such as in most Sub-Saharan Africa countries (Kenny/Moss 1998, 833; Afego 2015, 251).

Besides listed companies and investors, there are other actors which are important to make a stock exchange functioning and successful. These include various directly involved financial service providers such as brokers, clearing banks and houses, but there are also additional service firms which support investors, listed companies and further stock exchange stakeholders. These include consultancies, investment banks, rating agencies, analysts and others, which are important in making stock exchanges more efficient and transparent, and thus attractive to a wide variety of, also international, investors. Their presence in a national stock market location is a significant indicator for a stock exchange's professionalism 
and overall importance. For this reason, stock exchanges try to attract such service providers to their location and support them in establishing local branches, with the aim to benefit from their activities and international networks.

The vibrancy of the resulting localised network of stock exchange actors is an important success factor not only for the stock exchange itself, but also for the local and national business community, which is why business development agencies regularly represent a part of such networks, too. Furthermore, members (or owners) of the stock exchange and the regulatory agencies, policy makers and the state are important in setting up the legal and regulatory framework within which a stock exchange operates. Reliable regulation and good corporate governance of stock exchanges and beyond are central factors for companies and especially investors to become involved. This provides a special challenge for opaque and not-yet well-developed markets such as in Sub-Saharan Africa (Ncube/Mingiri 2015, 369), which is where the SSEI comes into play. Before taking a closer look at Sub-Saharan Africa stock exchanges and the SSEI, we will first explore Sub-Saharan Africa's role in international capital flows, specifically portfolio investment.

\section{International capital flows, stock exchanges and uneven development}

The exchange and flow of financial resources is distributed extremely unevenly throughout the world. With great consistency, by far the largest amount of capital flows occur between the economically advanced countries of the so-called Triad (North America, Europe and Japan/East Asia), reflecting the prominent role that leading industrialised nations play in the world economy and in trade relations. The types and directions of capital flows in the rest of the world, however, have changed, and emerging and developing economies have increased their shares in the last decades. This is especially the case for foreign direct investment (FDI), where these countries now account for a third of all FDI inflows, whereas their share of portfolio investment inflows is only 12\% (Balance of Payments data for 2008-2015 from IMF 2017).

As these deliberations indicate, international capital flows are made up of several components: the publicly available statistics generally differentiate direct investment, portfolio investment and bank loans as private capital flows on the one hand and government transfers, i.e. the exchange of central bank funds and money from state investment companies (sovereign wealth funds), on the other hand. Two other important sources of finance for emerging and developing economies are official development assistance (ODA) and remittances sent home by international migrants. In the present study, we concentrate on portfolio investment as this is where stock exchanges play the key role as investment channel. International portfolio investment is defined as "cross-border transactions and positions involving debt or equity securities, other than those included in direct investment or reserve assets" (IMF 2010, 110), which includes (minority) shareholdings in companies as major category.

Figures $2 \mathrm{a}$ and $2 \mathrm{~b}^{5}$ confirm the dominant position of the Global North - and here just a few countries (US, UK) or world regions (especially the Euro area) - as destination of portfolio investment, with a similar pattern for the countries of investment capital origin. Within emerging and developing economies there are also stark differences with relatively high volumes of portfolio investment in South and East Asia (incl. Mainland China) and in Latin America in contrast to consistently low values for Sub-Saharan Africa. While Sub-Saharan Africa accounts for about $14 \%$ of the world population and $2 \%$ of the global GDP (WB 2017a), its share of portfolio investment inflows is consistently well below 3\% between 2008 and 2015 . Furthermore, the most recent trend points downward with less than $1 \%$ in 2015, after a significant increase to $2 \%$ in 2011 in the wake of the financial crisis (WB 2017a). These data suggest that the euphoria surrounding Sub-Saharan Africa as an investment destination might have been short-lived.

The pattern of portfolio investment flows can easily be associated with the international stock exchange system which is highly uneven. In terms of listed companies, there are large exchanges not only in the Global North, but increasingly also in South and East Asia. However, when it comes to trading volumes, i.e. the total quantity of shares and contracts traded, there is a clear dominance of just very few exchanges, which are characterised by large domestic markets and well-above average shares of foreign listed companies. The three largest stock exchanges - the London Stock Exchange (LSE), Nasdaq and the New York Stock Exchange (NYSE), the latter two both located in New York - regularly account for well over half of global stock trading (Zademach 2014, 93). By contrast, the small

5 The figures give an overview of portfolio investment inflows for 2008 to 2015 and cover all years for which time series data of portfolio investment flows are available from the IMF Balance of Payments Database (IMF 2017). 
(a) Euro-Area (excl. ECB)

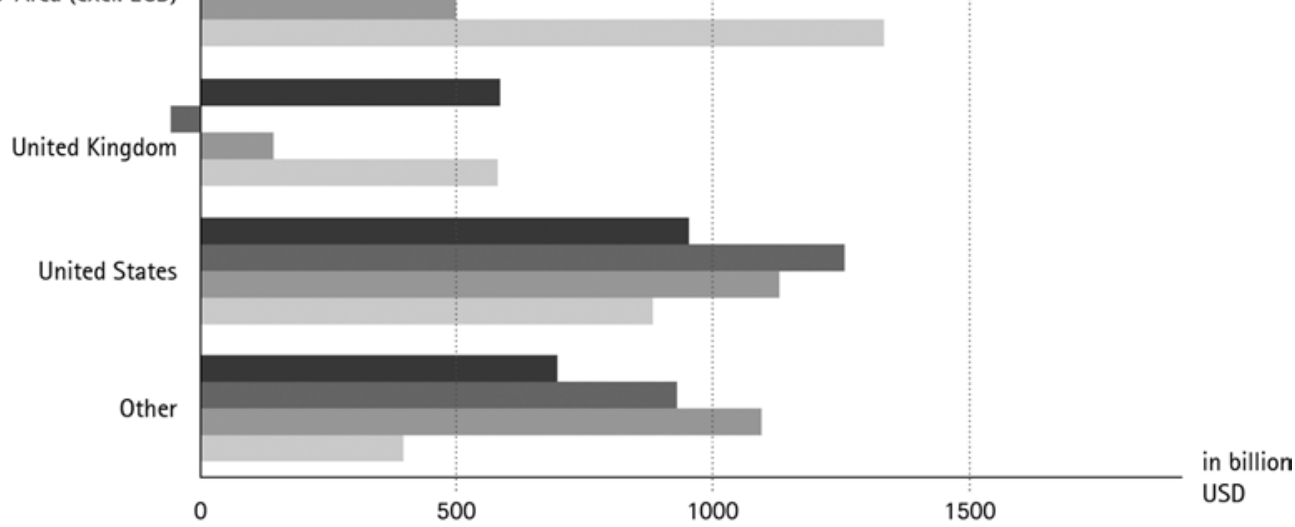

(b)

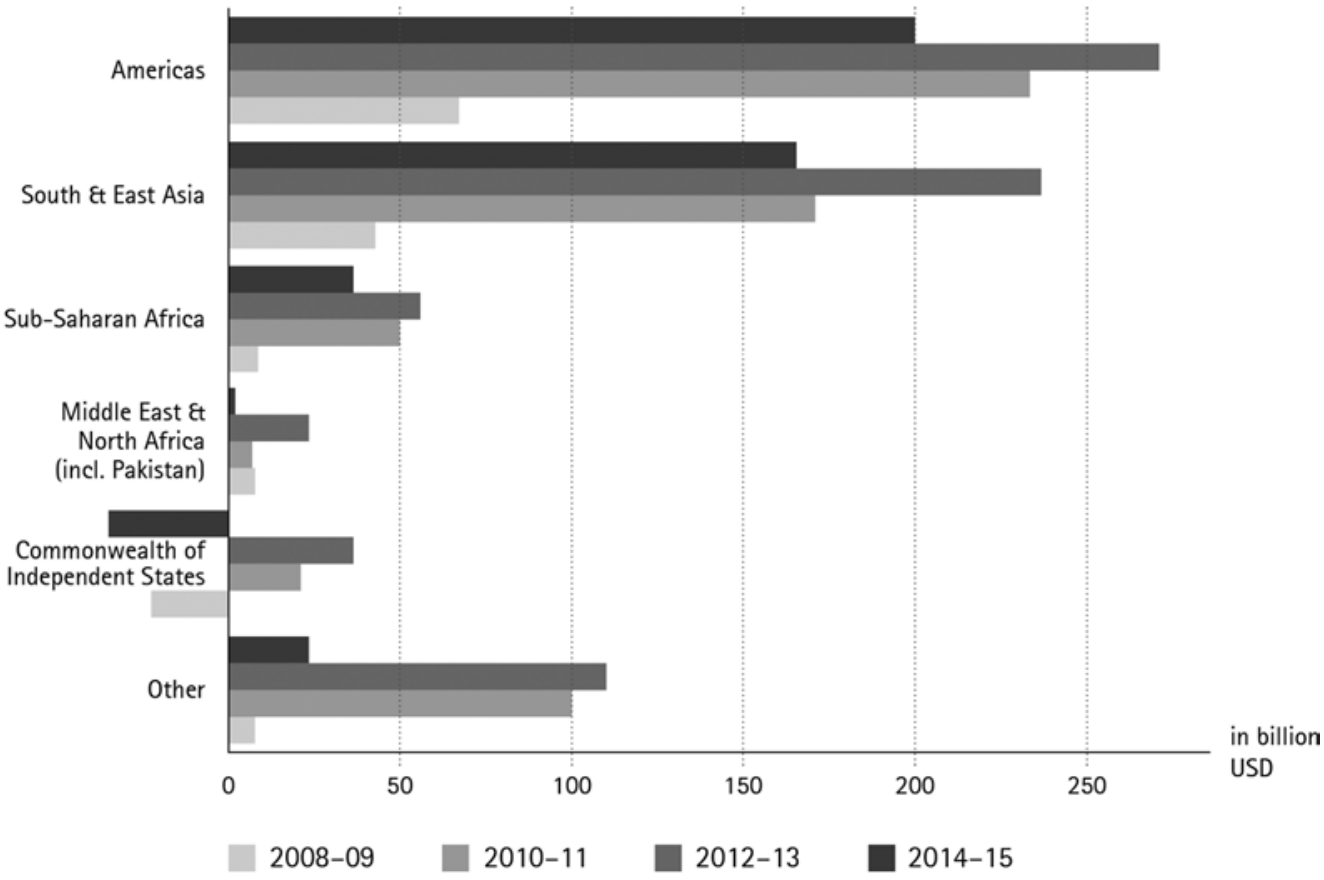

Figure 2: Portfolio investment inflows in (a) advanced economies and (b) emerging and developing economies (billion USD), $2008-2015$. Authors' illustration; data source: WB 2017 .

stock exchanges of Sub-Saharan Africa, many of which are not even members of the World Federation of Exchanges (WFE) and thus do not show up in Figure 3, accounted for less than $2 \%$ of global market capitalisation in 2010
(IFC 2011, 22) and an even lower share of trading volumes. Nonetheless, the development of Sub-Saharan African stock exchanges has been quite dynamic in the last decades, as we will show in the following section. 


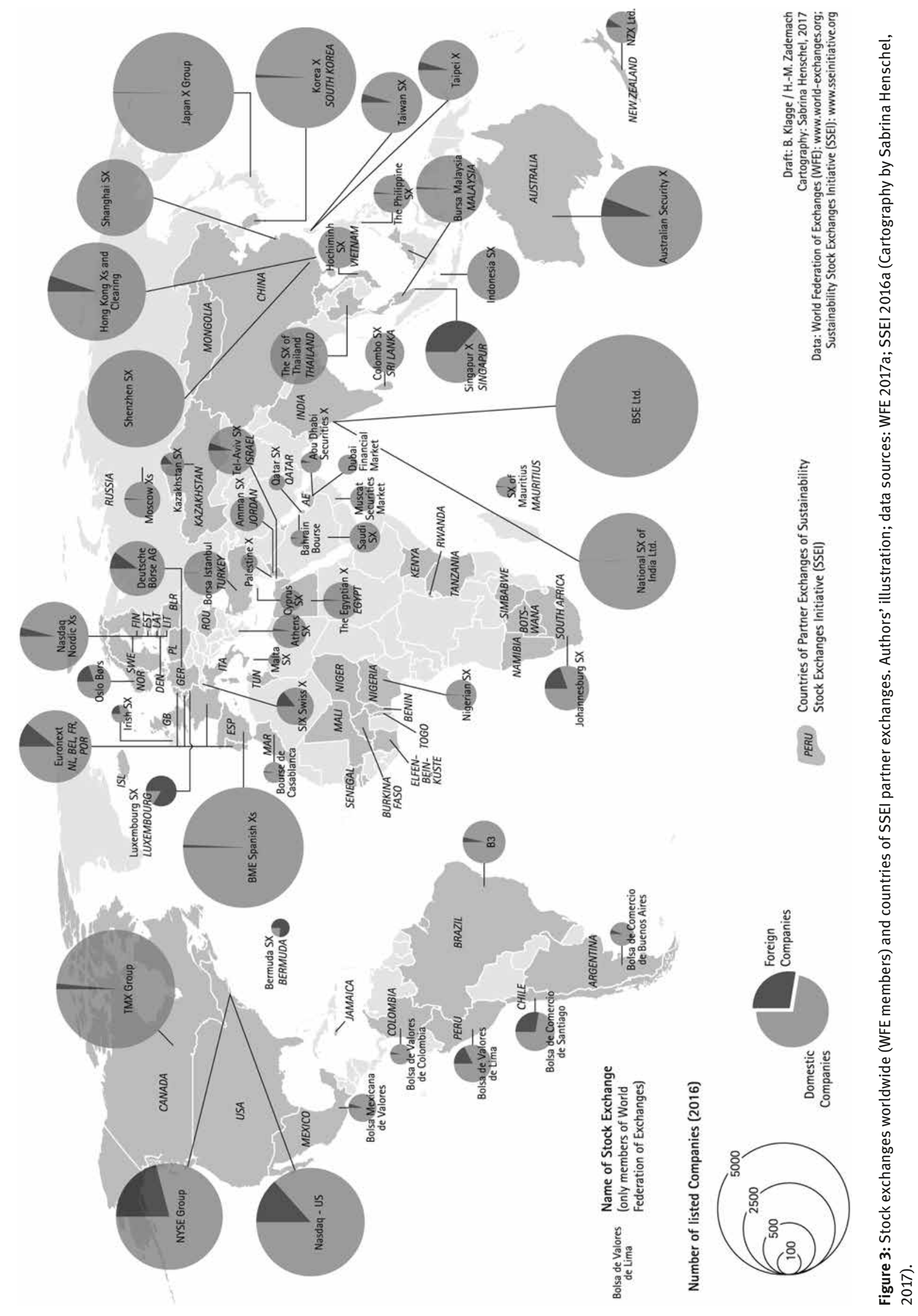




\section{Stock exchanges in Sub-Saharan Africa: dynamic developments, risks and opportunities}

Financial systems in Sub-Saharan Africa are diverse, but are generally regarded as "least developed even by standards of other developing regions" (Allen et al. 2011, 80). Nonetheless, the number of stock exchanges in the region has developed quite dynamically in the last decades, from only five in the early 1980s to more than 20 today (Table 1). While some Sub-Saharan Africa stock exchanges have a long history dating back to colonial times or the early years of independence (South Africa, Kenya, Nigeria), most are rather young institutions. A majority of 13 stock exchanges were established in the late 1980s and the 1990s, often to support the privatisation of state-owned enterprises and to facilitate foreign investment in the context of liberalisation policies and structural adjustment programs (Allen et al. 2011). This includes the foundation of the regional stock exchange BRVM in 1998, which serves eight francophone West African countries. The wave of stock exchange foundations abated after 2000; however, there were three further establishments in the 2000s and four since 2010. Membership data of the African Stock Exchange Association (ASEA) as of September 2017 counts 20 stock exchanges in Sub-Saharan Africa. Three recently founded stock exchanges in Somalia (2015), Angola (2016) and Lesotho (2016) are not yet members of ASEA (ASEA 2017).

Although some authors do see positive trends in stock market development in Sub-Saharan Africa (e.g. IFC 2011; Ncube/Mingiri 2015), it is generally agreed that "the dramatic increase in the number of exchanges ... has not been accompanied by improvements in the quality, depth, efficiency and competitiveness of stock exchanges in the region" (Afego 2015, 261). Sub-Saharan African stock exchanges are small and illiquid, also compared to stock exchanges in other parts of the developing world (Allen et al. 2011; IFC 2011). Many are not much more than electronic trading platforms and have only very few trading hours per week (Afego 2015, 249). According to Ncube/Mingiri (2015, 367), most African stock markets are "fragmented, lack economies of scale, and ... operational efficiency" as well as sophisticated financial service providers and infrastructures (IFC 2011, 34). The only exception is the Johannesburg Stock Exchange (JSE), which is by far the largest stock exchange in Sub-Saharan Africa and internationally well-recognised with more than 300 listed companies and a large domestic market capitalisation both in absolute and in relative terms (Table 1). In stark contrast, the number of listed domestic companies at other Sub-Saharan Af- rica stock exchanges is generally below 50. Exceptions are Nigeria, Mauritius and Kenya, but even in these relatively larger Sub-Saharan African stock markets the market capitalisation is more than 30 times smaller than at the JSE with a much lower percentage of GDP as well.

Most Sub-Saharan Africa stock exchanges also face the challenge of very low trading volumes and that trade concentrates in a few stocks; some are even dominated by a small number of firms. "There are serious informational and disclosure deficiencies for other stocks apart from the actively traded ones" (Ncube/Mingiri 2015, 369), which provides opportunities for large returns for those investors who have access to local knowledge (Bitala 2010; IFC 2011). Such opportunities, however, still bear a high level of risk, as currency rates, as well as political conditions, can fluctuate strongly and regulatory environments are weak due to a lack of rule of law and a high incidence of corruption in many Sub-Saharan African countries (IFC 2011; Afego 2015; Ncube/Mingiri 2015). All this makes Sub-Saharan Africa stock exchanges rather unattractive for most international and institutional investors and helps to explain the rather low portfolio investment inflows, although they "have performed remarkably well, both in terms of absolute returns and on a risk-adjusted basis" (Allen et al. 2011, 83).

Generally, Sub-Saharan Africa stock markets are perceived as challenging and high-risk markets, though with the potential of high returns (Kenny/Moss 1998; Allen et al. 2011; IFC 2011). This, together with the opportunity for portfolio and thus risk diversification, has resulted in an increased interest of international investors and the fund industry. It is against this background that there are various initiatives by Sub-Saharan Africa stock exchanges and the respective governments to increase liquidity and attract more investment, thus following the development-through-stock-exchanges argument outlined in section 2.1. Such initiatives can include large-scale privatisations and generally focus on improving institutional conditions, corporate governance and operational efficiency through (more) regulatory rigor, (better) compliance with international transparency and disclosure standards, but also upgrading (technology) infrastructure (for an early account see Kenny/Moss 1998). Additional suggested measures include an "appropriate mix of taxes, legal and regulatory policies to remove barriers to stock market operation ... [as well as] policies to encourage savings and investment [which] might infuse higher demand for capital market activities and engender greater integration of African stock markets into their economies" (Enisan/Olufisayo 2009, 170). 
Table 1: Sub-Saharan African stock exchanges: selected indicators.

\begin{tabular}{|c|c|c|c|c|c|c|c|c|}
\hline \multirow{2}{*}{$\begin{array}{l}\text { Year of } \\
\text { establish- } \\
\text { ment }\end{array}$} & \multirow{2}{*}{$\begin{array}{l}\text { SSEI mem- } \\
\text { bership } \\
\text { since }\end{array}$} & \multirow[t]{2}{*}{ Name of stock exchange } & \multirow[t]{2}{*}{$\begin{array}{l}\text { Conduct } \\
\text { business in }\end{array}$} & \multicolumn{2}{|c|}{$\begin{array}{l}\text { Number of listed } \\
\text { domestic companies }\end{array}$} & \multicolumn{3}{|c|}{$\begin{array}{l}\text { Market capitalization of domestic } \\
\text { companies }\end{array}$} \\
\hline & & & & 2010 & 2016 & Year & Billion USD & $\%$ of GDP \\
\hline 1887 & 2012 & Johannesburg Stock Exchange & South Africa & 352 & 303 & 2016 & 951.3 & 322.0 \\
\hline 1954 & 2015 & Nairobi Securities Exchange & Kenya & 55 & 65 & 2011 & 10.2 & 24.3 \\
\hline 1960 & 2013 & Nigerian Stock Exchange & Nigeria & 215 & 169 & 2016 & 29.8 & 7.4 \\
\hline 1989 & 2016 & Botswana Stock Exchange & Botswana & $16^{1}$ & n.a. & 2000 & 0.98 & 16.9 \\
\hline 1989 & & Ghana Stock Exchange & Ghana & 31 & $29^{1}$ & 2011 & 3.1 & 7.8 \\
\hline 1989 & 2015 & Stock Exchange of Mauritius & Mauritius & 62 & 75 & 2016 & 7.6 & 62.2 \\
\hline 1990 & & Swaziland Stock Exchange & Swaziland & $6^{1}$ & n.a. & 2007 & 0.2 & 6.8 \\
\hline 1992 & 2016 & Namibia Stock Exchange & Namibia & 7 & 8 & 2011 & 0.001 & 0.009 \\
\hline 1993 & 2015 & Zimbabwe Stock Exchange & Zimbabwe & $69^{1}$ & n.a. & 1999 & 2.5 & 35.9 \\
\hline 1994 & & Malawi Stock Exchange & Malawi & n.a. & n.a. & & n.a. & n.a. \\
\hline 1994 & & Lusaka Stock Exchange & Zambia & 20 & n.a. & 2010 & 3.2 & 13.6 \\
\hline $1994^{*}$ & & Khartoum Stock Exchange & Sudan & n.a. & n.a. & & n.a. & n.a. \\
\hline 1996 & 2016 & Dar es Salaam Stock Exchange & Tanzania & $4^{1}$ & n.a. & 2001 & 0.4 & 3.8 \\
\hline 1997 & & Bolsa de Valores de Mozambique & Mozambique & n.a. & n.a. & & n.a. & n.a. \\
\hline 1997 & & Uganda Securities Exchange & Uganda & n.a. & n.a. & & n.a. & n.a. \\
\hline 1998 & 2015 & $\begin{array}{l}\text { Bourse Régionale des Valeurs } \\
\text { Mobilières (BRVM) }\end{array}$ & $\begin{array}{l}8 \text { West African } \\
\text { countries }^{2}\end{array}$ & 39 & 43 & 2016 & 12.4 & 34.0 \\
\hline $2001^{\star}$ & & Douala Stock Exchange & Cameroon & n.a. & n.a. & & n.a. & n.a. \\
\hline $2005^{*}$ & 2015 & Rwanda Stock Exchange & Rwanda & n.a. & n.a. & & n.a. & n.a. \\
\hline $2009^{*}$ & & Sierra Leone Stock Exchange & Sierra Leone & n.a. & n.a. & & n.a. & n.a. \\
\hline $2011^{*}$ & 2016 & Seychelles Securities Exchange & Seychelles & - & 8 & & n.a. & n.a. \\
\hline 2015 & & Somali Stock Exchange & Somalia & - & n.a. & & n.a. & n.a. \\
\hline 2016 & & Bolsa de Dívida e Valores de Angola & Angola & - & n.a. & & n.a. & n.a. \\
\hline 2016 & & Maseru Securities Market & Lesotho & - & n.a. & & n.a. & n.a. \\
\hline
\end{tabular}

Data obtained from

IFC, *ASEA SSEI

Notes: ${ }^{1}$ Latest available data: Zimbabwe (1999), Botswana (2000), Tanzania (2001), Swaziland (2007), Ghana (2013). ${ }^{2}$ Benin, Burkina Faso, Guinea Bissau, Côte d'Ivoire (HQ), Mali, Niger, Senegal, Togo. n.a.: not available. Authors' compilation; data sources: ASEA 2017; IFC 2011; SSEI 2013a; WB 2017b.

In their efforts to create (more) enabling environments, Sub-Saharan Africa stock exchanges learn from other stock exchanges and can also get support and guidance from international financial institutions and trade associations. However, apart from JSE, Nigeria and Mauritius, none of the Sub-Saharan stock exchanges is a member of the World Federation of Exchanges (WFE), the global industry association for stock exchanges and clearing houses. In contrast, 11 out of 23 are affiliated with the SSEI, i.e. they are listed as partner exchanges (Table 1). A reason for this discrepancy probably is that membership in the WFE is associated with a fee, whereas becoming a 
partner exchange of the SSEI is free of charge; only the SSE Commitment Letter has to be signed.

\section{The Sustainable Stock Exchange Initiative - change agent or market maker?}

The Sustainable Stock Exchange Initiative was established in 2009, right after the start of the most recent global financial crisis, as a peer-to-peer learning platform to enhance corporate sustainability and encourage responsible longterm approaches to investment. Its organisers are a "quartet" of three UN organisations, United Nations Conference on Trade and Development (UNCTAD), UN Global Compact (UNGC), United Nations Environment Programme Finance Initiative (UNEP-FI), and the UN-supported Principles for Responsible Investment Initiative (PRI). While the SSEI invites stock exchanges globally to become SSEI partners, it also welcomes supporting participation of other stakeholders such as regulators, policy makers, standard setters, investors and companies, e.g. in the SSEI's Consultative Group or its biennial Global Dialogues (Figure 4). It thus addresses all relevant actor groups involved in stock exchange activities and networks as depicted in section 2.2 and Figure 1.

Participating stock exchanges are required to commit to advance sustainability in their markets by publicly endorsing the following statement: "We voluntarily commit, through dialogue with investors, companies and regulators, to promoting long term sustainable investment and improved environmental, social and corporate governance disclosure and performance among companies listed on our exchange" (SSEI 2013b). While sustainability is the much-used key term of the initiative with repeated reference to environmental, social and governance (ESG) issues and also the sustainable development goals (SDGs), the SSEI places special emphasis on good corporate governance and corporate transparency more generally. ${ }^{6}$ As such, the SSEI is much more than another sustainability initiative, but at the same time also a high-profile initiative to improve the investment conditions in developing and emerging markets. From a market-making perspective, the SSEI provides a striking example for "the formatting of specific market agencies ... to guarantee the frictionless

6 For a more general overview on recent trends in the markets of sustainable finance and socially responsible investments see e.g. Haigh (2012) and Zademach (2015).

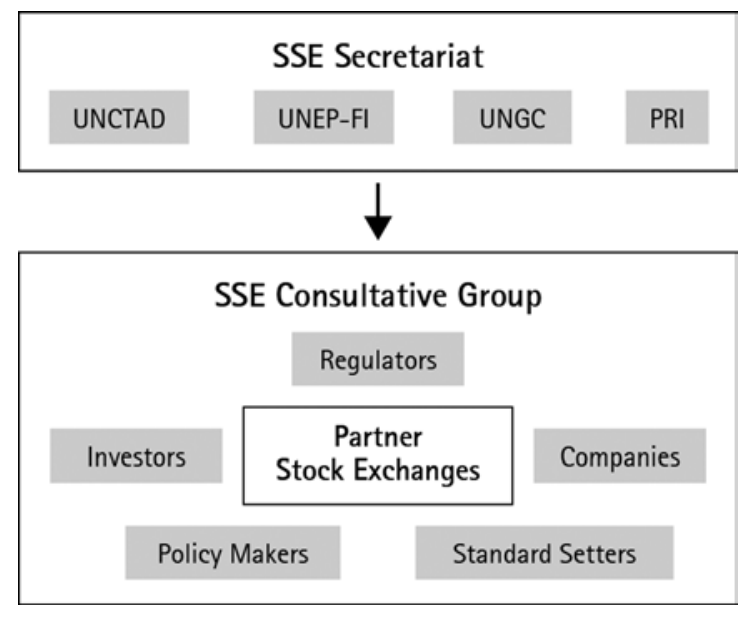

Figure 4: SSEl's operational structure. Source: SSEI 2013b, adopted.

circulation of goods and capital at new spatial scales" (Ouma 2015, 37).

The SSEI's focus on emerging markets is corroborated by the development of its partner exchanges which are predominantly active in the Global South (Figure 5). Sub-Saharan Africa stock exchanges account for $20 \%$ of all partner exchanges (if regional groups such BRVM, Nasdaq Nordic and Euronext are counted as one stock exchange) and - due to the regional stock exchange in West Africa an even higher percentage of the countries covered within the SSEI. Sub-Saharan Africa is only surpassed by Europe \& CIS (Commonwealth of Independent States) with its large number of countries, which probably also reflects the strong commitment to climate policies and sustainability goals in the EU and Europe more generally. Overall, however, there are at least a few partner exchanges from each world region, and the SSEI partner exchanges cover a broad size spectrum ranging from very large international exchanges (NYSE, LSE, Deutsche Börse), all of them located in the Global North, to very small and rather illiquid exchanges, mainly in the Global South.

With the successful acquisition of 66 stock exchanges representing almost 70 countries, the regular SSEI activities and the cooperation with various high-profile stakeholders, including not only UN-related organisations, the SSEI has become an important stock exchange platform for negotiating sustainability and ESG issues. But the scope of the SSEI goes far beyond, as it can be regarded as a market maker in various respects. It has been contributing to further develop the market for sustainable or green finance and shift it from a niche into the global mainstream market. By obliging stock exchanges worldwide - and with them regulators, investors and various others - to pursue sustainable development and business 


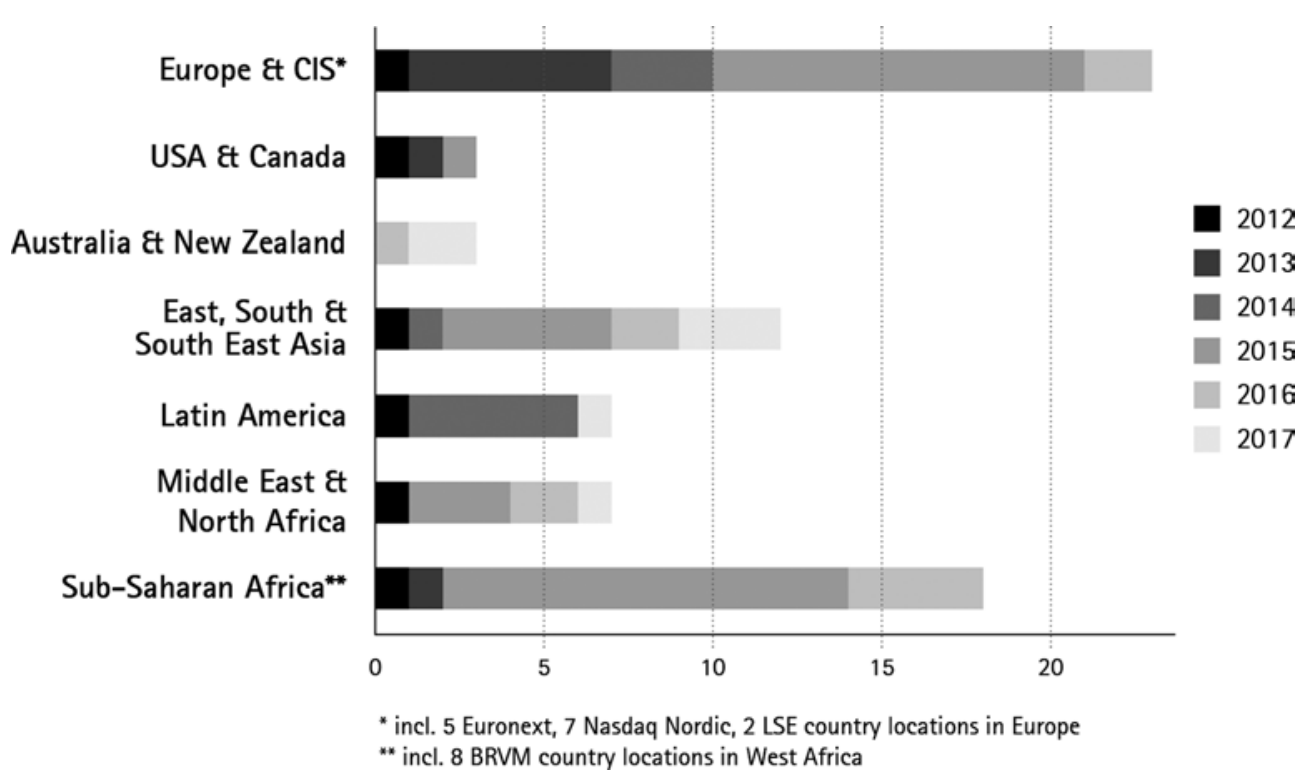

Figure 5: Development of SSEI partner exchanges by world region (multiple listings for exchanges covering more than one country). Authors' illustration; data source: SSEI 2013c.

practices, the SSEI has also provided a fertile ground for new demand for financial and consulting services, which are then offered and provided by firms based in the Global North or South Africa. ${ }^{7}$ The growing global importance of the SSEI for sustainable finance is supported by the fact that the Luxembourg Stock Exchange eventually joined the SSEI in 2016. The Luxembourg Stock Exchange sees itself as "the leading stock exchange in the world for the listing of green bonds with 100 listings, and as a capital markets intermediary committed to a sustainable economy" (SSEI 2016a) and already played a leading role in the SSEI Executive Dialogue on Green Finance later the same year in Nairobi (SSEI 2016b).

In addition to promoting sustainable and green finance markets, the SSEI plays a market making role also in geographical perspective. By supporting stock exchanges in developing and emerging markets to better comply with international transparency and disclosure standards, it makes these markets more attractive to international investors and thus helps them to expand their activities and diversify their portfolios. That this happens with a focus

7 Good examples are the boutique investment advisory firm SinCo and the financial analyst and investment consultancy RisCura, from the US and South Africa respectively. The two firms, which researched and drafted the IFC report on sustainable investment in Sub-Saharan, forecast a strong growth of sustainable investment in this region, but deplore the lack of financial service infrastructure as well as present themselves as specialist service providers for sustainable investment in Africa and other emerging markets (IFC 2011, 4, 34, 47, 59). on - or perhaps rather under the guise of - sustainable development is an interesting feature. It reminds of other sustainability initiatives or corporate environmental strategies which employ the notion of sustainability and the like as rhetoric, as a means to create new markets, or to influence or even curb future regulation (e.g. Sharma/Vredenburg 1998; Haigh 2012; Ilgaz/Zademach 2015; Klagge/ Reimer 2016). Following this line of thought, we will, in the next section, look at Sub-Saharan Africa stock exchanges in greater detail and explore their SSEI engagement.

\section{The Sustainable Stock Exchange Initiative in Sub-Saharan Africa}

The SSEI has, end of 2017, eleven partner exchanges in Sub-Saharan Africa which cover 18 out of 48 countries. While the Johannesburg SE and Nigerian SE were among the early members of the initiative, all other entered the SSEI in 2015 and 2016. However, of all these stock exchanges only very few have fulfilled anything except endorsing the general statement required to become a member ( $\mathrm{Ta}$ ble 2). Most of them do not (yet) require ESG reporting as a listing rule, offer written guidance on ESG reporting or related training, or have sustainability related indices or green bond listings (also see IFC 2011).

However, even without these activities, the partner exchanges have become part of a network which meets regularly and in which best-practices regarding ESG and cor- 
Table 2: SSEl partner exchanges in Sub-Saharan Africa and their sustainability engagement.

\begin{tabular}{|c|c|c|c|c|c|c|c|c|}
\hline $\begin{array}{l}\text { Name of stock } \\
\text { exchange }\end{array}$ & $\begin{array}{l}\text { SSEI mem- } \\
\text { bership } \\
\text { since }\end{array}$ & $\begin{array}{l}\text { Has prepared } \\
\text { SSE commu- } \\
\text { nication to } \\
\text { stakeholders }\end{array}$ & $\begin{array}{l}\text { Requires ESG } \\
\text { reporting as a } \\
\text { listed rule? }\end{array}$ & $\begin{array}{l}\text { Offers written } \\
\text { guidance on } \\
\text { ESG reporting? }\end{array}$ & $\begin{array}{l}\text { Offers ESG } \\
\text { related } \\
\text { training? }\end{array}$ & $\begin{array}{l}\text { Provides } \\
\text { sustainability- } \\
\text { related indices? }\end{array}$ & $\begin{array}{l}\text { Has green } \\
\text { bond } \\
\text { listings? }\end{array}$ & $\begin{array}{l}\text { WFE mem- } \\
\text { bership }\end{array}$ \\
\hline $\begin{array}{l}\text { Botswana Stock } \\
\text { Exchange }\end{array}$ & 2016 & - & - & - & - & - & - & no \\
\hline $\begin{array}{l}\text { Bourse Régionale } \\
\text { des Valeurs } \\
\text { Mobilières } \\
\text { (BRVM) }\end{array}$ & 2015 & - & - & - & - & - & - & no \\
\hline $\begin{array}{l}\text { Dar es Salaam } \\
\text { Stock Exchange }\end{array}$ & 2016 & - & - & - & - & - & - & no \\
\hline $\begin{array}{l}\text { Johannesburg } \\
\text { Stock Exchange }\end{array}$ & 2012 & $x$ & $x$ & $x$ & $x$ & $x$ & $x$ & yes \\
\hline $\begin{array}{l}\text { Nairobi Securities } \\
\text { Exchange }\end{array}$ & 2015 & $x$ & - & - & - & - & - & no \\
\hline $\begin{array}{l}\text { Namibia Stock } \\
\text { Exchange }\end{array}$ & 2016 & - & - & - & - & - & - & no \\
\hline $\begin{array}{l}\text { Nigerian Stock } \\
\text { Exchange }\end{array}$ & 2013 & $x$ & - & - & $x$ & - & n.a. & yes \\
\hline $\begin{array}{l}\text { Rwanda Stock } \\
\text { Exchange }\end{array}$ & 2015 & - & - & - & - & - & - & no \\
\hline $\begin{array}{l}\text { Seychelles } \\
\text { Securities } \\
\text { Exchange }\end{array}$ & 2016 & - & $x$ & - & - & - & - & no \\
\hline $\begin{array}{l}\text { Stock Exchange } \\
\text { of Mauritius }\end{array}$ & 2015 & - & - & - & - & - & - & yes \\
\hline $\begin{array}{l}\text { Zimbabwe Stock } \\
\text { Exchange }\end{array}$ & 2015 & n.a. & n.a. & n.a. & n.a. & n.a. & n.a. & no \\
\hline
\end{tabular}

n.a.: not available. Authors' compilation; data sources: SSEI 2013a, 2013d; WFE 2017b.

porate governance are exchanged and capacities around the concept of Sustainable Finance are built. This includes already four SSEI events in Africa, in Abuja (2015), Nairobi (2016), Marrakesh (2016) and Casablanca (2017). In the run-up of the Nairobi meeting three Sub-Saharan Africa stock exchanges (Botswana, Namibia, Tanzania) announced their partnership with the SSEI. This illustrates how these meetings not only serve to discuss and develop strategies for partner exchanges, but also function as occasions to raise awareness and attract new members in the respective world region.

The SSEI events are often held as part of or in association with other international meetings focusing on sustainability (e.g. UNCTAD World Investment Forum, UN Climate Summit, meeting of financial centre representatives). SSEI events are meeting places for a variety of different actors, including, apart from stock exchanges, also regulators, investors, financial service companies, international organisations and others. This mix, which is reflected in the SSEI's Consultative Group (cf. Figure 4), allows for an integrated approach to discuss best-practice - in ESG, but also corporate governance and its implementation - and to develop stock exchange strategies, activities and networks accordingly. Maybe most importantly, bringing together all these different types of mostly internationally active stakeholders with (national) stock exchange representatives provides opportunity for knowledge exchange and trust-building.

Overall, the way the SSEI is organised and organises its events is thus not only promoting ESG issues, but also helps stock exchanges to build relationships with international investors and other actors and vice versa. It pro- 
vides, on the one hand, especially small stock exchanges with an opportunity to attract these actors and/or their business to their locations and thus increase their investor base and enlarge local stock exchange networks (cp. Figure 1 and section 2.2). On the other hand, the participating investors and financial service firms can gain local or even exclusive knowledge on so-far opaque markets, especially those with an assumed high potential such as in Sub-Saharan Africa, and include them into their future (portfolio diversification) strategies. For the time being, it is not clear, who are the main beneficiaries of such developments. However, the fact that international investors and international service firms take an active part in SSEI and its events is a clear indication that opening up new markets is part of the rationale.

\section{Discussion and conclusion}

The integration of Sub-Saharan Africa into global capital markets and circuits is still weak, but there is an increasing interest in Africa's economies and also in its stock markets. However, Sub-Saharan Africa stock markets, with the notable exception of the Johannesburg Stock Exchange, are rather small and illiquid which deters international and institutional investors and has kept portfolio investment in Sub-Saharan Africa at a very low level (well below FDI flows). In this situation, the SSEI's initiative provides a timely effort to support African as well as other exchanges worldwide in further developing their governance structures and to include sustainability and ESG issues into their strategies - which would make them more attractive to domestic companies as well as investors, especially from abroad. The regulatory changes, which the involvement with the SSEI might trigger, are important conditions for enhancing transparency, reliability and possibly also the sustainability of doing business at these stock exchanges. Maybe even more importantly, however, the SSEI also functions as a platform which connects, and supports trust-building between, representatives of national stock exchange and other local stakeholders (incl. regulators) with a variety of mainly international actors including investors, rating agencies, analysts, lawyers, consultants etc.

As we have outlined in our conceptual account, the SSEI thus induces regulatory changes and the building of networks which are important in turning national stock exchanges into intermediaries between domestic companies and international investors. Who are the beneficiaries if such a development materialises and Sub-Sa- haran Africa becomes better integrated into the world economy via its stock exchanges and through international portfolio investment? If one follows the development-through-stock-exchanges argument, Sub-Saharan Africa economies benefit from the resulting integration into international capital circuits. However, our explorative account of Sub-Saharan Africa stock exchanges and the SSEI also shows, that the potential beneficiaries are not only located in Africa. International investors and other financial service firms are actively searching for new business fields and regions to expand and specifically diversify their activities. Africa, and especially Sub-Saharan Africa, is given high priority on their agenda, though in many parts not yet perceived as "investor-ready". The SSEI provides the participating international companies with an opportunity to gain exclusive knowledge, build personal relationships and thus attain first-mover advantages with respect to doing business in Africa. Additionally, especially given the emphasis some African governments put on stock exchanges, it also needs to be examined to what extent stock market development is associated with collusion and "looting-by-political-elite" (cp. AIPC 2017, 3).

The challenge for Sub-Saharan Africa stock exchanges and other local stakeholders is therefore to develop their national stock exchange networks and business partnerships in a way which allows for reaping a fair share of the benefits domestically and not let international firms, possibly in collusion with local political elites, dominate African economies (incl. stock exchanges) yet another time. This is especially important in light of the potential adverse effects of stock markets on the domestic economy, particularly short-termism and selectivity which are especially prevalent among large international investors. It will be worthwhile from a regional and social development viewpoint to further follow-up whether and how the SSEI supports Sub-Saharan Africa stock exchanges in forming and establishing their own profiles regardless of the interests of international finance, thus not only functioning as a market maker, but also as a change agent for sustainable and endogenous development in Sub-Saharan Africa.

Acknowledgements: The authors acknowledge helpful comments on earlier versions of the paper from the participants of the Financial Geography Lab at the Frankfurt School in November 2017, particularly Ewa Karwowski and Eike Schamp who also gave detailed written comments, and two very constructive and inspiring anonymous reviews. In addition, the authors wish to thank Gerda Jeusfeld and Sabrina Henschel for their great research assistance and all the work with the map and figures. Klagge 
would also like to thank the Deutsche Forschungsgemeinschaft (DFG) to have approved the sub-project "Energy Futures: Infrastructures and governance for renewable energies" within the newly established collaborative research center CRC228 "Future Rural Africa”, allowing future research on financing renewable energies in Africa. The usual disclaimers apply.

\section{References}

Afego, P. N. (2015): Market efficiency in developing African stock markets: what do we know? In: The Journal of Developing Areas, 49(1), 243-266.

AIPC (African Investigative Publishing Collective) (2017): The plunder route to Panama. How African oligarchs steal from their countries. Internet: https://www.zammagazine.com/images/ pdf/documents/African_Oligarchs.pdf, 18 November 2017.

Allen, F./Otchere, I./Senbet, L. W. (2011): African financial systems. A review. In: Review of Development Finance, 1(2), 79-113.

Arcand, J.-L./Berkes, E./Panizza, U. (2012): Too much finance? Washington, D.C. (=IMF Working Papers, Working Paper No.12/161).

ASEA (African Securities Exchanges Association) (2017): Membership. Internet: http://www.african-exchanges.org/en/ membership\#contentCarousel/members, 9 November 2017.

Asongu, S. A./De Moor, L. (2017): Financial globalisation dynamic thresholds for financial development: evidence from Africa. In: The European Journal of Development Research, 29(1), 192-212.

Baumol, W. J. (1965): The stock market and economic efficiency. New York: Furham University Press.

BDI (Bundesverband der Deutschen Industrie e.V.) (2015): Afrika - Krisen- oder Chancenkontinent? Internet: https://bdi.eu/themenfelder/internationale-maerkte/ chancenkontinent-afrika/\#/artikel/news/afrika-krisen-oder-chancenkontinent/, 29 March 2018.

Beck, T. (2012): The role of finance in economic development benefits, risks, and politics. In: Mueller, D. C. (Eds): Oxford Handbook of Capitalism. Oxford: Oxford University Press, 161-203.

Berndt, C./Boeckler, M. (2012): Geographies of marketization. In: Barnes, T.J./Peck, J./Sheppard, E. (Eds): The Wiley-Blackwell Companion to Economic Geography. Oxford: Wiley, 199-212.

Bitala, M. (2010): Ghana - erfolgreichster Aktienmarkt der Welt. Internet: http://www.sueddeutsche.de/geld/afrika-boersen-ghana-erfolgreichster-aktienmarkt-der-welt-1.113770, 9 November 2017.

Demirgüç-Kunt, A./Levine, R. (1996): Stock market development and financial intermediaries: stylized facts. In: The World Bank Economic Review, 10(2), 291-321.

Dike, C. (2016): Stock market efficiency promotes economic development: empirical evidence from Africa. In: International Journal of Economics and Financial Issues, 6(3), 1287-1298.

Dörry, S. (2015): Strategic nodes in investment fund global production networks: The example of the financial centre
Luxembourg. In: Journal of Economic Geography, 15(4), 797-814.

Dörry, S. (2017): Regulatory spaces in global finance. In: Martin, R./ Pollard, J. (Eds): Handbook on the Geographies of Money and Finance. Cheltenham: Edward Elgar, 415-433.

Dymski, G. A. (2005): Discrimination in the credit and housing markets: findings and challenges. In: Rodgers, W. (Eds): Handbook on the Economics of Discrimination. Cheltenham: Edward Elgar, 215-259.

Enisan, A. A./Olufisayo, A. O. (2009): Stock market development and economic growth. Evidence from seven sub-Sahara African countries. In: Journal of Economics and Business, 61(2), 162-171.

Grote, M. H. (2009): Financial centers between centralization and virtualization. In: Alessandrini, P./Fratianni, M./Zazzaro, A. (Eds): The Changing Geography of Banking and Finance. New York: Springer, 277-294.

Haigh, M. (2012): Connecting sustainability goals to financing activity (Editorial). In: Journal of Sustainable Finance \& Investment 2(2), 85-87.

IFC (International Finance Corporation) (2011): Sustainable Investment in Sub-Saharan Africa. Investment practitioner views of sustainable investment in private equity and asset management in South Africa, Nigeria, and Kenya. Internet: http://www.ifc.org/wps/wcm/connect/65c3300048865905b7f af76a6515bb18/IFC_Sustainable_Investment_in_Sub-Saharan_ Africa.pdf?MOD=AJPERES\&CACHEID $=65$ c3300048865905b7faf 76a6515bb18, 29 March 2018.

Ilgaz, S./Zademach, H.-M. (2015): Performative Praktiken am Kapitalmarkt: das Beispiel nachhaltige Geldanlagen in Deutschland. In: Zeitschrift für Wirtschaftsgeographie, 59(4), 243-258.

IMF (International Monetary Fund) (2010): Balance of payments manual. Sixth edition. Washington, D.C. (=Manuals \& Guides, Band 2009). Internet: http://www.imf.org, 9 November 2017.

IMF (International Monetary Fund) (2017): Balance of payments (BOP). Internet: http://www.imf.org, 9 November 2017.

Kenny, C. J./Moss, T. J. (1998): Stock markets in Africa: emerging lions or white elephants? In: World Development, 26(5), 829-843.

Keynes, J. M. (1936): The general theory of employment, interest and money, New York: Harcourt Brace.

Klagge, B./Martin, R./Sunley, P. (2017): The spatial structure of the financial system and the funding of regional business: $a$ comparison of Britain and Germany. In: Martin, R./Pollard, J. (Eds): Handbook on the Geographies of Money and Finance. Cheltenham: Edward Elgar, 125-155.

Klagge, B./Peter, C. (2011): Changes in the German urban system. A financial-sector perspective. In: Raumforschung und Raumordnung, 69(3), 201-211.

Klagge, B./Peter, C. (2012): Knowledge management in the network mode. The case of private equity. In: Urbani izziv, 23(1), 74-84. Internet: http://urbani-izziv.uirs.si/Portals/uizziv/papers/ urbani-izziv-en-2012-23-supplement-1-007.pdf, 18 November 2017.

Klagge, B./Reimer, S. (2016): Carbon offsetting and corporate strategies: case-study findings of large German firms. In: Jones, A./Ström, P./Hermelin, B./Rusten, G. (Eds): Services and the Green Economy. Basingstoke: Palgrave Macmillan, 171-193. 
Levine, R. (2002): Bank-based or market-based financial systems: which is better? In: Journal of Financial Intermediation, 11(4), 398-428.

Levine, R. (2005): Finance and growth: theory and evidence. In: Aghion, P./Durlauf, S. (Eds): Handbook of Economic Growth. Amsterdam: Elsevier, 865-934.

Levine, R./Zervos, S. (1998): Stock markets, banks, and economic growth. In: The American Economic Review, 3(88), 537-558.

Lucas, R. E. (1988): On the mechanics of economic development. In: Journal of Monetary Economics, 22(1), 3-42.

Martin, R. (1999): The new economic geography of money. In: Martin, R. (Ed.): Money and the Space Economy. Chichester: Wiley, 3-28.

McKinnon, R. (1973): Money and capital in economic development. Washington, D.C.: The Brookings Institution.

Myrdal, G. (1957): Economic theory and underdeveloped regions. London: Duckworth.

Ncube, G./Mingiri, K. F. (2015): Stock market integration in Africa. The case of the Johannesburg stock exchange and selected African countries. In: International Business \& Economics Research Journal (IBER), 14(2), 367-386.

Ouma, S. (2015): Assembling export markets: the making and unmaking of global food connections in West Africa. Chichester, UK: John Wiley \& Sons.

Peter, C. (2018): Wissensmanagement in Private Equity-Netzwerken und die Rolle regionaler Finanzzentren in Europa (= Wirtschaftsgeographie, Bd. 57). Münster: LIT Verlag.

Rodríguez-Fuentes, C. J. (2006): Regional monetary policy. London: Routledge.

Schamp, E. W. (2009): Das Finanzzentrum - ein Cluster? Ein multiskalarer Ansatz und seine Evidenz am Beispiel von Frankfurt/RheinMain. In: Zeitschrift für Wirtschaftsgeographie, 53(1-2), 89-105.

Schumpeter, J. A. (1912): Theorie der wirtschaftlichen Entwicklung. Leipzig: Dunker \& Humblot.

Sharma, S./Vredenburg, H. (1998): Proactive corporate environmental strategy and the development of competitively valuable organizational capabilities. In: Strategic Management Journal, 19(8), 729-753.

Singh, A. (1999): Should Africa promote stock market capitalism? In: Journal of International Development, 11(3), 343-365.

SSEI (Sustainable Stock Exchanges Initiative) (2013a): Stock exchanges fact sheets. Internet: http://www.sseinitiative.org/ data/fact-sheets/, 9 November 2017.

SSEI (Sustainable Stock Exchanges Initiative) (2013b): Frequently asked questions (FAQs). Internet: http://www.sseinitiative.org/ about/faq/\#1, 9 November 2017.

SSEI (Sustainable Stock Exchanges Initiative) (2013c): News. Internet: http://www.sseinitiative.org/news/, 9 November 2017.
SSEI (Sustainable Stock Exchanges Initiative) (2013d): List of partner exchanges. Internet: http://www.sseinitiative.org/sse-partner-exchanges/list-of-partner-exchanges/, 9 November 2017.

SSEI (Sustainable Stock Exchanges Initiative) (2016a): Latest UN SSE partner exchange leader in green bond listings. Internet: http://www.sseinitiative.org/home-slider/latest-un-sse-partner-exchange-leader-in-green-bond-listings/, 9 November 2017.

SSEI (Sustainable Stock Exchanges Initiative) (2016b): Executive dialogue on green finance. Internet: http://www.sseinitiative. org/green-finance/, 9 November 2017.

Stiglitz, J. (2010): Freefall: free markets and the sinking of the global economy. London: Penguin.

SWR (Südwestrundfunk) (2017): Chancenkontinent Afrika? Privatinvestitionen und fairer Handel. Internet: https://www.swr.de/ international/swraktuellmondial/chancenkontinent-afrika/-/ id $=2900538 /$ did=18851070/nid=2900538/1qmcfyv $/$ index. html, 29 March 2018.

Vives, A./Wadhwa, B. (2012): Sustainability indices in emerging markets: impact on responsible practices and financial market development. In: Journal of Sustainable Finance \& Investment, 2(3-4), 318-337.

WB (World Bank) (2017a): Open data. Balance of payments. Internet: https://data.worldbank.org/, 9 November 2017.

WB (World Bank) (2017b): World development indicators. Internet: https://data.worldbank.org/data-catalog/world-development-indicators, 9 November 2017.

WFE (World Federation of Exchanges) (2017a): The role of stock exchanges in fostering economic growth and sustainable development. Internet: https://www.world-exchanges.org/ home, 9 November 2017.

WFE (World Federation of Exchanges) (2017b): WFE members. Internet: https://www.world-exchanges.org/home/index.php/ members/wfe-members, 9 November 2017.

Wójcik, D. (2007): Geography and the future of stock exchanges. Between real and virtual space. In: Growth and Change, 38(2), 200-223.

Wójcik, D./Burger, C. (2010): Listing BRICs. Stock issuers from Brazil, Russia, India, and China in New York, London, and Luxembourg. In: Economic Geography, 86(3), 275-296.

Yartey, C. A. (2008): The determinants of stock market development in emerging economies. Is South Africa different? Washington, D.C. (=IMF Working Papers, Working Paper No. 08/32).

Zademach, H.-M. (2014): Finanzgeographie. Darmstadt: WBG.

Zademach, H.-M. (2015): Gutes Tun und Geld verdienen? Ethische Investments und nachhaltige Geldanlagen. In: Geographische Rundschau, 67(2), 46-52. 